\title{
Innovative Invention Skills and Individual Competency Model for Vocational Education
}

\author{
Mimi Mohaffyza Mohamad, Nor Lisa Sulaiman, Kahirol Mohd Salleh, and Lai Chee Sern
}

\begin{abstract}
Invention is a process of developing creative minds, innovative and inventive in preparing the workforce informed, and competent in facing the challenges of rapid technological development today. Knowledge and individual competency are needed to produce a new design of a product. Knowledge and skills are the components related to invention process that could be identified easily. Therefore, this study aimed to determine the level of student's knowledge and preferences in invention process, student's skills in selecting the process knowledge, and to identify the relationship between the student's knowledge and the preferences process that they chose. 528 students from vocational colleges were involved in this study. The set of questionnaires based on Renwick model and iceberg competency model was used to measure the variables needed. The results showed the level of student's knowledge in invention process was high and the students also preferred the idea of development when they chose the invention process. This study also concluded that there was a significant relationship between knowledge and student's preferences in invention process. In conclusion, the application of skills and knowledge in invention process will be applied in students' competency and it is capable of developing new ideas to create innovative and creative products.
\end{abstract}

Index Terms-Invention, knowledge, skills, and vocational colleges.

\section{INTRODUCTION}

In applying the elements of creativity and innovation, students need to grow their ideas when they are given opportunities in their activities [1]. According to [2], the competencies to conduct cognitive, effective, and psychomotor reflect the knowledge, skills, and ability to achieve. Students who have high competence will have high interest in everything they do and have the attitude of a sense of responsibility to their assignment or task related to problem solving. The statement issued by [3] in which invention is a subject that uses a combination of three dimensions or the mind concepts, skills and attitudes or values of the task or problem. As a result, the combination of these three dimensions will produce an idea that starts with the mind. Accordingly, the present application of their skills on the invention reserved by vocational students can produce students who are competent and skilled in their fields to meet

Manuscript received November 20, 2015; revised June 2, 2016. This work was supported in part by UniversitiTun Hussein Onn Malaysia (UTHM); Grant R042.

The authors are with the Faculty of Technical and Vocational Education, Universiti Tun Hussein Onn Malaysia, 86400 Parit Raja, BatuPahat, Johor, Malaysia (e-mail: mimi@uthm.edu.my, norlisa@uthm.edu.my, kahirol@uthm.edu.my, lcsern@uthm.edu.my). the needs of industry, and thus can achieve the goals contained in the vocational curriculum. A high level of competence in students will also show good performance in work and has the markets to meet the needs of industry. Therefore, vocational college students need to have a creative mind and innovation in themselves through their curriculum copyright, in line with the objectives of vocational college students which to create and produce high-level job competence that can meet the needs of industry. Through education process, it could enhance the skills of students in solving problems by applying the knowledge and skills acquired at the vocational college. Moreover, students and creators can be simultaneously produced in the future.

\section{INVENTION PROCESS MODEL}

The process of designing a series of stages; are interdependent on each other will focus on creative and critical thinking and could ultimately result in a product prototype that can be evaluated based on the specific criteria according to the invention [4]. Referring to [5], the process of designing can be very flexible, as they can be structured and adapted to meet the needs of various problems. Fig. 1 and Table I shows the process of invention in producing a new design.

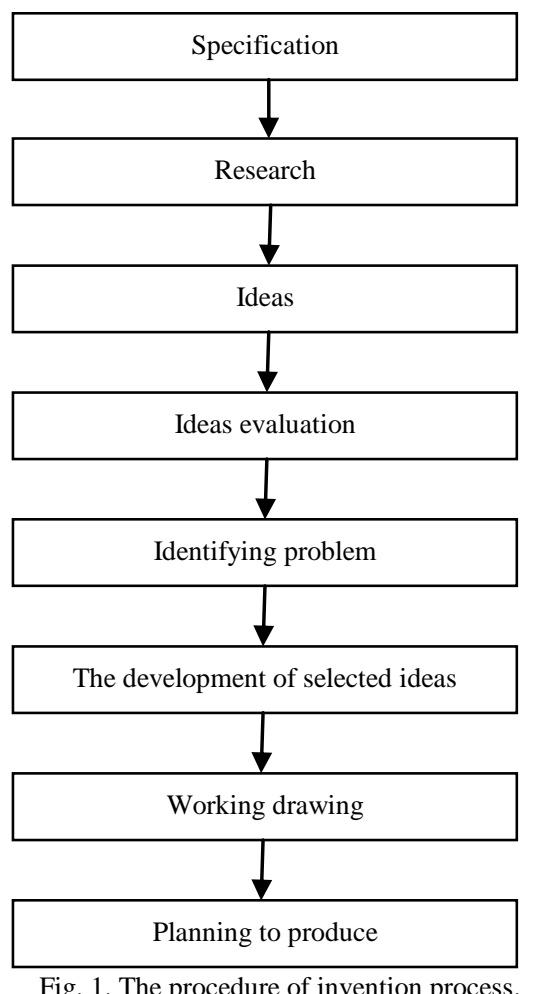

Fig. 1. The procedure of invention process. 
TABLE I: DESCRIPTION OF INVENTION PROCESS

\begin{tabular}{ll}
\hline \hline \multicolumn{1}{c}{ Process } & Description \\
\hline Identifying problem & $\begin{array}{l}\text { The problems are identified in advance, } \\
\text { then the problems existedareanalyzed and } \\
\text { understood using free sketches, notes, and } \\
\text { images that can help to understand the } \\
\text { issue. }\end{array}$ \\
\hline Specification & $\begin{array}{l}\text { Specifications of what arerequired such } \\
\text { as materials, equipment, and procedures are } \\
\text { determined. }\end{array}$ \\
\hline Research & $\begin{array}{l}\text { The proposed product design is studied } \\
\text { with complete information and data about } \\
\text { the proposal with sketches, notes, drawings, } \\
\text { diagrams, charts, and questionnaires. }\end{array}$ \\
\hline Ideas & $\begin{array}{l}\text { Creative ideas for products to be } \\
\text { manufactured are proposed and initial } \\
\text { sketches and ideas using a variety of } \\
\text { techniques are made. }\end{array}$ \\
\hline Planningto produce \\
Thelected ideas
\end{tabular}

\section{A. Competency Model}

The competency model describes a combination of competence that could be linked to a specific task to generate an excellent output. A competency is an individual characteristic that can be measured or counted reliably and can be shown to significantly differentiate between superior and average performers, or between effective and ineffective performers. Competency can be described as a set of behavior patterns that an incumbent needs to bring to a position in order to perform the tasks and functions to delivering the desired results or outcomes [6]; while [7] viewed competency as an underlying characteristic of an individual that is causally related to criterion-referenced effective and superior performance in a job or situation. They identified five types of competency characteristics, which consist of motives, traits, self-concept, knowledge, and skills. Firstly, motives are the things that an individual consistently thinks about or wants that stimulate an action. Motives drive, direct, and select the behavior towards certain actions or goals and away from others. Secondly, traits are the physical characteristics and consistent responses to situations or information. Thirdly, self-concept is an individual's attitudes, values or self-image. Fourthly, knowledge is the information that an individual has in specific areas. Finally, skill is the ability to perform a certain physical or mental task. Knowledge and skill competencies tend to be visible and relatively surface characteristics, whereas self-concept, traits, and motive competencies are more hidden, deeper, and central to personality. Surface knowledge and skill competencies are relatively easy to develop and training is the most cost-effective way to secure those abilities [7].

Fig. 2 explains the iceberg competency model, which consists of seven (7) categories of competence and divided into two groups. The group on the surface is called the knowledge and skills competencies group which are shown as the top part of the iceberg. The competence group consists of skills and knowledge competencies. The group on the bottom level of the iceberg is the collection of behavioral competence. The competence group consists of few categories including the competence, social roles, self-image, character, and motive. Knowledge and skills are conspicuous component competencies and identify personal characteristics of the supporting components. This component is an important factor in the effort to establish members with the knowledge and skills required. All categories of competence are central to the self of an individual in executing a task.

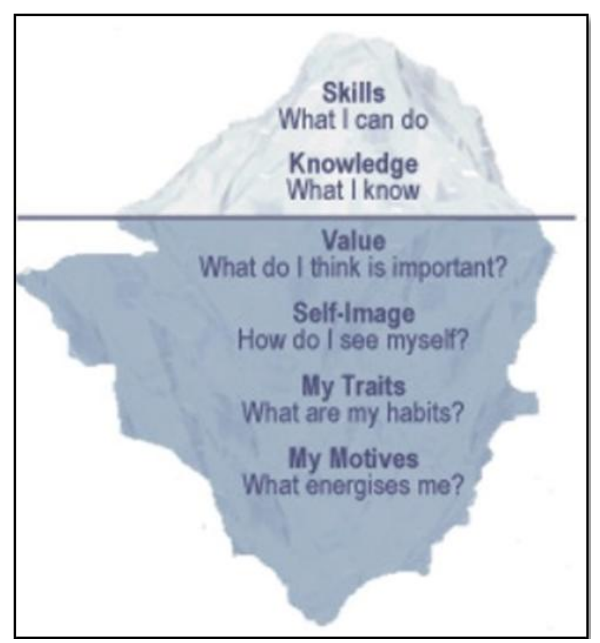

Fig. 2. Iceberg competency model.

\section{RESEARCH METHOD}

A survey research design that applied descriptive and inferential quantitative approach was carried out to determine the level of knowledge of students in invention process based on Renwick model and iceberg competency model. The focus on competencies in the surface area involved knowledge and skills. The relationship between the level of knowledge of students in the process of designing and the tendency of students in the process of designing was studied. The variables were based on the process of invention by [5] and the competence of the students' knowledge in the process of designing. In this research, the primary objective of the study was to identify the level of knowledge of students in the process of designing, the aptitudes in the process of designing, the students that chose skills to design, and the relationship between the level of knowledge of students in the process of designing and the trends of students in the process of designing. 528 vocational students were involved in this research and they were required to answer the questionnaires based on the invention process and competency criteria. The research objectives were:

1) To identify students' knowledge in invention process;

2) To identify students' preferences in invention process;

3) To know students' skill in invention activities; 
4) To investigate the relationship between knowledge and students' preferences in invention process.

\section{RESULT}

This research involved 528 vocational college students in Malaysia and consisted 425 male and 103 female. They are enrolled in technology courses; mechanical and manufacturing technology, electrical and electronic technology, and construction technology. For the first research objective, the level of knowledge of students in the process they created was showed that based on the analysis that has been done. The items that earned the highest mean score (mean score 4.19) was the $43^{\text {rd }}$ item with the question "I prefer to read materials to add my knowledge". In the meantime, the lowest item was the $45^{\text {th }}$ item with the question "I am able to relate previous knowledge to generate design ideas" (with a score of 4:08). This indicates that the knowledge of students in the process of designing is based on the mean score higher than average. The mean score of students' in stage of designing process is 4.22 and it was described that students tend to perform activities of developing ideas. To know the student's skill in invention activities, the situation of designing product was given. Students have to decide which process they prefer to see the extent of their skills in the process of designing. Most of the respondents have a tendency to choose as their process of copyright as specified by their process copyright [5]. In answering this question, students are more likely to do activities with the idea of doing a selection over another. To answer the fourth question, namely whether there is a relationship between the level of students' knowledge in designing and the trends process students in the process of designing. The results showed a significant relationship at a high level of correlation between the level of knowledge of students in the process of designing and the tendency of students in the process of designing in which the value of $p$ was $<0.05$.

The results showed students have high level of knowledge in the process of the invention and students also prefer the idea of choice when choosing the design process. There was a significant relationship between students' knowledge and the selection of process they created. In conclusion, the application of skills and knowledge in the process they created improves competency and students are able to develop new ideas to create innovative and creative products.

\section{DISCUSSION}

Majority of vocational students have a high level of knowledge in designing process. Knowledge is also synonym with the domination in science in which when a student has mastered any field, they will become confident and in they can create a creative and innovative product [8]. This shows that students should have knowledge and skills competencies in designing an adequate process before they step into the career world someday so they are well prepared and not surprised by the nature of the work in the future. The majority of vocational students have a high level of process they created in each design process. The development of the idea of choice in the context of the designing process is based on the idea that has been developed to show how the design process is produced [5]. The researchers found that students in vocational college tended to process because in this process there are a number of elements needed by students to hone their creative thinking skills. The prototype is a product developed at the early stage of production for the purpose of developing the idea of choice among students. At this stage, the prototype will allow and enable students to fully understand how to produce the products whether it is hard or easy.

Hence, in the process they created, students can be exposed to a variety of soft skills are required by the students. An invention is a unique thing that can provide a wide exposure to students in science, technology, and entrepreneurship. The designing process must be taken seriously especially in finding the ways to overcome challenges. With a curriculum that is based on invention, students are able to realize the delivery of process creates innovative teaching, it is more student-centered, and more flexible approaches are included in the curriculum that has been reoriented in order to take into account certain issues such as the development of information technology, environment, culture, international language, entrepreneurship, and the requirements of service industry which is growing rapidly.

Thinking skills are applied in doing things and students are able to generate their ideas in the production of opinion that is deemed appropriate. Knowledge is also one of the key factors in producing invention process. If the students have a high level of knowledge, it will be easier for them to carry out the process of invention and thus they can develop marketable and innovative products. In the context of knowledge competency, it is the ability to continuously upgrade their knowledge to improve their own performance effectively. This could be seen when a student has the knowledge of design process and continuously practicing this process can improve the copyright of students in the lower level up to high level. The researcher identified that when a student can master their knowledge in accordance with the proper process they created, they will be able to save energy, costs, and time. Thus, when students have the tendency to invent the process of selecting, the correct user can establish student excellence in design so creative and innovative invention can be successfully produced.

\section{CONCLUSION}

In summary, this research which was related to curriculum copyrights aimed to produce students with creative and innovative skills and knowledge such as problem-solving skills. With any application of skills and knowledge, students will be able to adapt to the changes in technology through their inventions. Accordingly, with the implementation of designing technology process on the students in vocational colleges, a society with creativity will be produced through their respective skills and this will indirectly make the students better in preparing for their future career and they will be able to solve problems creatively. 


\section{ACKNOWLEDGEMENT}

The author would like to acknowledge University Tun Hussein Onn Malaysia and Ministry of Higher Education for providing the grant to conduct this research.(R042)

\section{REFERENCES}

[1] U. Zaini, Menjana Minda Kreatifdan Inovatif (Siri Perutusan Tahun Baru Naib Canselor), Skudai: Penerbit UTM Press, 2004.

[2] M. W. V. Haris, "Designing the best: A review of effective teaching and learning of design and technology," International Journal of Technology and Design Education, vol. 13, pp. 223-241, 2003.

[3] A. M. Royo and H. Mahmood, "Faktor-faktor kelemahan yang mempengaruhi pencapaian cemerlang dalam mata pelajaran reka cipta," Journal of Education Psychology and Counseling, vol. 2, pp. 145-174, Jun. 2011.

[4] A. H. M. Azhar, Kreativiti: Teori, Konsep dan Praktis, Skudai, Penerbit UTM, Universiti Teknologi Malaysia, 2006.

[5] P. Renwick, "Teaching and evaluating the problem solving process," Starting to Teach Design and Technology: A Helpful Guide for Beginners Teachers, Singapore: Prentice Hall, 2004, pp. 3-12.

[6] V. Vichita and T. N. Jintawee, "Competency requirements for effective job performance in the Thai public sector," Contemporary Management Research, vol. 3, no. 1. pp. 45-70, 2007.

[7] L. Spencer and S. Spencer, Competence at Work, Models for Superior Performance, New York: John Wiley \& Sons, Inc., 1993.

[8] G. Araz, "An integrated multi-criteria decision making methodology for outsourcing management," Computers and Operations Research, vol. 34, pp. 3738-3756, 2007.

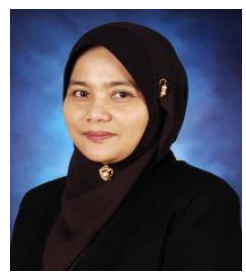

Mimi Mohaffyza Mohamad was born in Johor, Malaysia. Her background of education is related in technical and vocational education and training (TVET). She completed the bachelor degree in civil engineering technology and education from Univiersiti Teknologi Malaysia (UTM), the master and doctor of philosophy in technical and vocational education also graduated from UTM. She is senior lecturer in Faculty of Technical and Vocational Education, Universiti Tun Hussein Onn Malaysia. Currently, she is the head department of Professional Education Department. Her publication and research interest are in teaching and learning especially in TVET. Few publications related was published in journal and conference proceedings are; Applying Standard Competency Assessment in Vocational Practices (Asian Social Science Journal, 2015); Disparity of Learning Styles and Cognitive Abilities in Vocational Education (International Journal of Social, Behavioral, Education, Economic Business and Industrial Engineering, 2014), Conceptions of Learning Styles and Cognitive Dimension in Vocational Education (Journal of Technical Education and Training, 2014) and on going research grants in innovations, teaching and learning in TVET.

She is also a senior member of International Economics Development Research, National Union Teaching Profession. She is a reviewer for few journals such are British Journal of Applied Sciences and Technology, British Journal of Education, Society and Behavioral Sciences, Scientific Committee World Academy of Science.

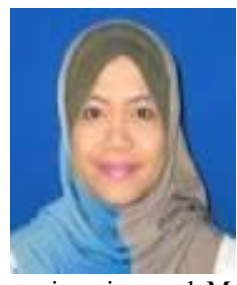

Nor Lisa Sulaiman has approximately 17 years of working experience in higher education sector and her passion for research and teaching will never fade. In the early years of her career, she has been appointed as faculty member and assistant director under the Ministry of Education and Ministry of Higher Education in her home country, Malaysia. She received a B.Sc. (Hons.) in electronic communication engineering and M.Ed. in technical education from Universiti Teknologi Malaysia. She continued her quest for knowledge by earning her Ph.D. in education and human resource studies from Colorado State University (CSU), Fort Collins, U.S.A. At present, she joins University of Tun Hussein Onn Malaysia (UTHM) as a faculty member and actively participates in research projects and publications at national and international levels in the field of Technical and Vocational Education and Training (TVET). Her primary TVET research interests include critical thinking, curriculum, instruction and leadership equivalent to her expertise in Leadership, Renewal and Change with concentration in Curriculum and Instruction (Critical Thinking). Her current job gives her the opportunity to meet TVET experts in Malaysia and various countries across all the continents. She wishes to have more connections in exploring new possibilities and interests to further expand her knowledge and skills in her specific areas of research.

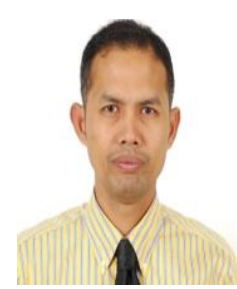

Kahirol Mohd Salleh has earned almost 17 years of experience working as faculty member and assistant director with higher learning institutions including Ministry of Education and Ministry of Higher Education in his country, Malaysia. Currently, he works as faculty member at University of Tun Hussein Onn Malaysia (UTHM). Apart from that he is actively participating in numerous researches involves national and international levels, relatively to his expertise in organization, performance, and change; within career and technical education field. His substantive education background has influenced his career path especially when he graduated his Ph.D. in education and human resource studies from Colorado State University (CSU), Fort Collins, USA in 2012. After completing his doctoral program, he was granted CSU Presidential Fellowship award for his noble contribution on his area of research. Due to his success stories, he is selected as post-doctoral student in research methodology where he was also worked as Teaching Assistant at the same university, CSU. As Malaysian who is still developing his research knowledge and skills, he wishes to continue conducting more research with other researchers to learn more about their research perspectives and cultures.

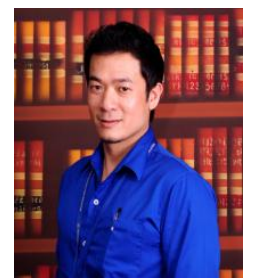

Chee Sern Lai was born in Butterworth, Malaysia, in 1975. He earned his B.Engin mechanical engineering and M.Ed in technical and vocational education from theUniversitiTun Hussein Onn Malaysia (UTHM), in 2002 and 2004 respectively. In 2010, he obtained his $\mathrm{PhD}$ in Engineering Education at the University of Bremen, Germany. He is an academic staff in the Faculty of Technical and Vocational Education, UTHM, since 2004. Meanwhile, he is holding a post as the head of Advanced Center for Technical and Vocational Education. He is actively involved in research projects related to technical and vocational education and teacher education. In specific, his main areas of research interest are concerning teaching and learning, cognitive load, and green skills. 